\title{
Primary Colon Lymphoma Presenting with Obstructive and Hemorrhagic Symptoms
}

\section{Obstrüktif ve Hemorajik Semptomlarla Seyreden Primer Kolon Lenfoması}

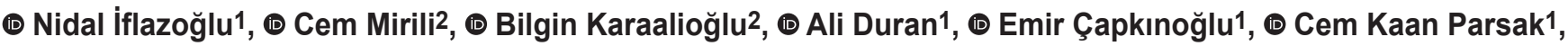

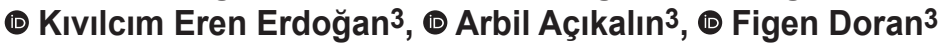

${ }^{1}$ Çukurova University Faculty of Medicine, Department of Surgical Oncology, Adana, Turkey

${ }^{2}$ Çukurova University Faculty of Medicine, Department of Medical Oncology, Adana, Turkey

${ }^{3}$ Çukurova University Faculty of Medicine, Department of Pathology, Adana, Turkey

\section{HIIIIII ABSTRACT}

Colorectal lymphomas comprise less than $1 \%$ of colorectal malignancies and $1 \%$ of non-Hodgkin lymphomas. Colonic lymphomas are usually diagnosed after surgical resection performed due to complications. Herein we present the management of a rare case of non-Hodgkin ascending colon lymphoma in a 57-year-old female patient with obstructive and hemorrhagic symptoms. Although surgery treats the complications, non-surgical therapies (chemotherapy and radiotherapy) are the mainstays of treatment for lymphoma, and surgery is not considered a priority for lymphoma treatment.

Keywords: Colon, lymphoma, obstructive, hemorrhagic

\section{|IIIIIII| ÖZ}

Kolorektal lenfomalar, kolorektal malignitelerin \%l'inden azını ve non-Hodgkin lenfomaların \%l'ini oluşturur. Kolonik lenfomalar genellikle komplikasyonlar nedeniyle yapılan cerrahi rezeksiyonlar sonrasında tanı alır. Burada obstrüktif ve hemorajik semptomları olan 57 yaşındaki bir olgu üzerinden nadir görülen bir non-Hodgkin çıkan kolon lenfomasının yönetimi sunulmaktadır. Cerrahi komplikasyonları tedavi etse de, cerrahi olmayan tedaviler (kemoterapi ve radyoterapi) lenfomanın ana tedavisidir ve cerrahi tedavi lenfomanın öncelikli tedavisi olarak kabul edilmez.

Anahtar Kelimeler: Kolon, lenfoma, tıkayıcı, hemorajik

\section{Introduction}

Colorectal lymphomas comprise less than $1 \%$ of colorectal malignancies and $1 \%$ of non-Hodgkin lymphomas. ${ }^{1}$ Diagnosis is usually delayed due to non spesific symptoms such as abdominal pain, fatigue and weight loss. Herein we present the management of non-Hodgkin ascending colon lymphoma, which is a rare condition.

\section{Case Report}

A 57-year-old female patient was admitted with abdominal pain, fatigue and abdominal swelling that had been persisting for 3 months. There were sympoms of partial bowel obstruction such as difficulty in passing flatus and feces. Her medical history was uneventful, except for cigarette smoking of 30 packs/year. Her aunt had gastric carcinoma. On physical examination, blood pressure was 100/70 $\mathrm{mmHg}$, heart rate: $105 \mathrm{bpm}$; there was a firm, immobile mass lesion in the right lower quadrant on palpation. The other body parts were normal (no pathological lymph node, etc.). Laboratory test results revealed a white blood cell count of 4200x103/uL, hemoglobin: $7.1 \mathrm{~g} / \mathrm{dL}$, hematocrit: $22.4 \%$, and the biochemistry test results were normal. Thoracic and abdominal computed tomography (CT) revealed a $15 \times 15 \mathrm{~cm}$ 
of tumor mass in the ceacum (Figure 1). Esophago-gastroduodenocopy revealed antral gastritis and high degree of helicobacter pylori positivity. Colonoscopy revealed a hemorrhagic, fragile mucosa over the hepatic flexura and an obstruction beginning from that point, preventing the colonoscope to move to the proximal colon. Multiple biopsies were obtained from this region and pathology examination revealed non-specific colitis. The patient was prepared for operation with the preoperative diagnosis of a mass lesion leading to hemorrhage and obstruction in the right colon. Right hemicolectomy + partial ileum resection + ileocolostomy were performed due to the mass lesion involving the ileal segments (Figure 2). The patient was discharged on postoperative day 5 . Subsequent to discharge wound infection developed which was handled in an outpatient setting.

The resected specimen was $48 \mathrm{~cm}$ in length and mass lesion was seen to be adhered to the small intestine in macroscopic examination. The proximal and the distal surgical borders were intact. On microscopic examination, hematoxylin and eosin 400x magnification revealed infiltration composed of large lymphoid cells (Figure 3). CD3, CD5, cycline D1, CD43 and CD23 were found to be negative on immune histochemical examination. CD20 was determined to be positive (Figure 4). Under the light of these data, the patient was evaluated as diffuse large B-cell colonic non-Hodgkin lymphoma.

${ }^{18}$ fluoro deoxyglucose positron emission tomography $\left({ }^{18}\right.$ FDG PET )-CT, which was performed for postoperative staging, revealed lymph nodes located in the mesenteric fat tissue in the operative field with a maximum diameter of 1.5 $\mathrm{cm}$, with standard uptake ratio maximum: 15 , and relatively increased ${ }^{18} \mathrm{FDG}$ uptake in the bone marrow. The disease was located at the abdomen (colonic involvement, 10-12 $\mathrm{cm}$, extranodal area) and more than one lymph node had been involved. Bone marrow aspiration and bone marrow biopsy did not reveal infiltration. The patient was noted not have B symptoms (fever, weight loss, night sweats) preoperatively. According to these results, the patient was considered to have stage $2 \mathrm{E}$ disease according to the Lugano Ann Arbor classification. International Prognostic Index (IPI) and National Comprehensive Cancer Network ${ }^{\circledast}$ IPI scores were low (0 score), low intermediate (2 score) with regard to risk scoring. ${ }^{2}$

We planned 6 cycles of rituximab, cyclophosphamide, doxorubicin, vincristine, prednisone (R-CHOP) chemotherapy and sequential radiotherapy (RT) under the light of the current literature and guidelines. The result of ${ }^{18}$ FDG PET$\mathrm{CT}$, which was performed in order to assess the response after the second cycle of chemotherapy, the disease was determined to have completely regressed. The treatment of the patient continues uneventfully. The written consent of the patient about publication has been taken during the outpatient clinic control.

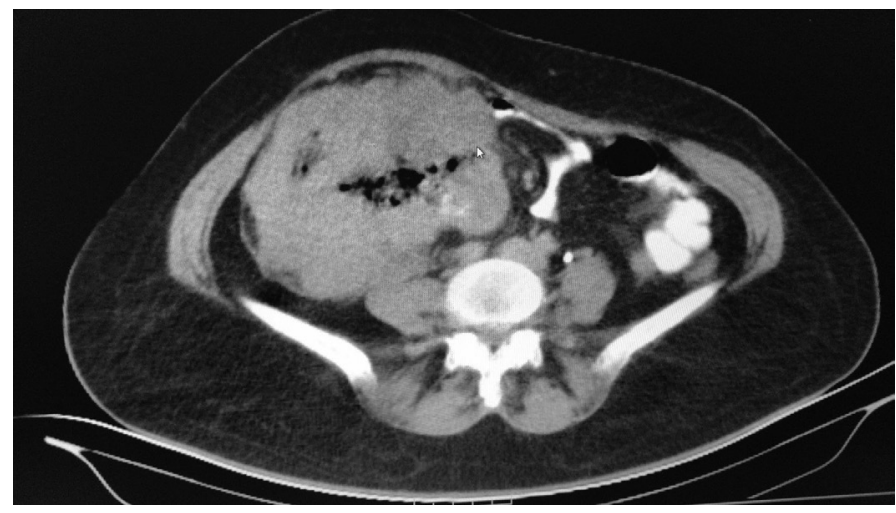

Figure 1. Computed tomography image of caecal mass lesion

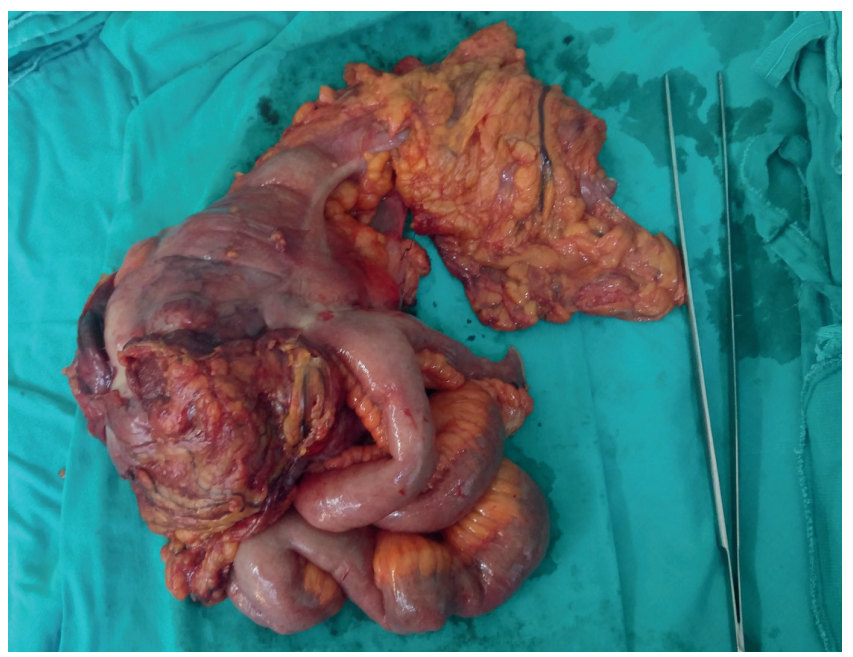

Figure 2. Operative material of right hemi-colectomy + partial ileal resection

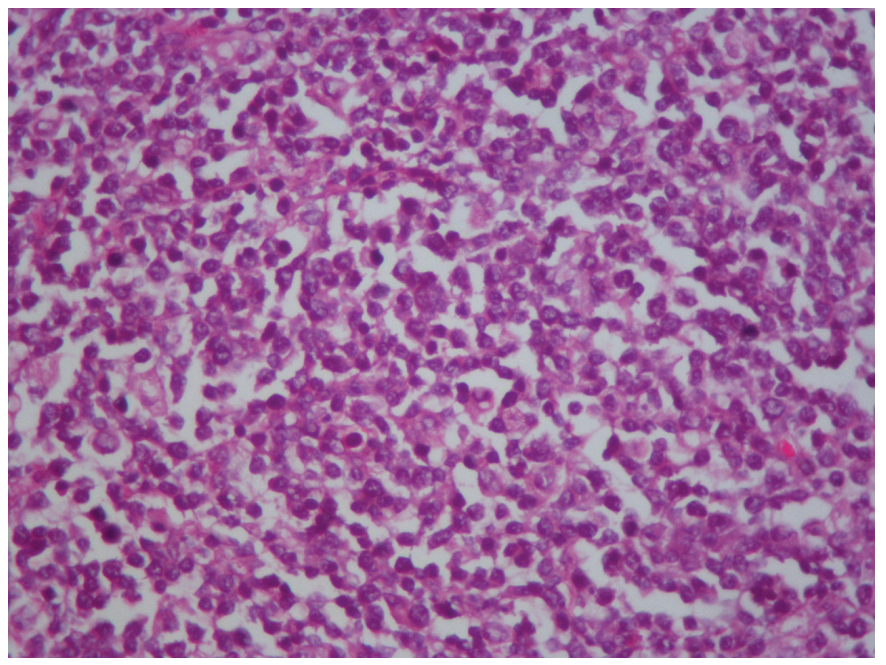

Figure 3. Large magnification has revealed the infiltration composed of atypical, large lymphoid cells ( $4000 \mathrm{H} \& \mathrm{E})$ 


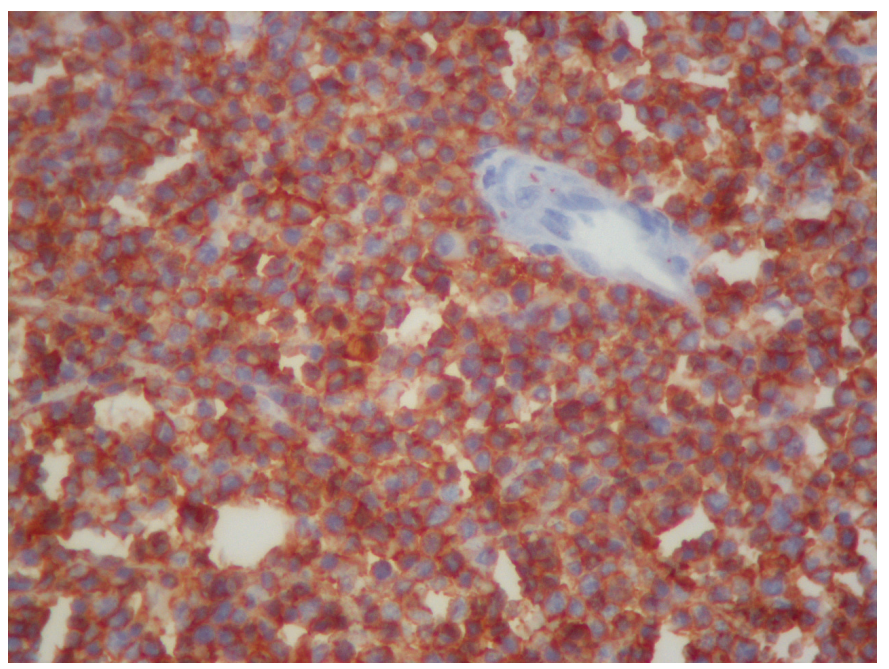

Figure 4. Atypical lymphoid cells were seen to be CD20 positive (CD20, $\mathrm{x} 400$ )

\section{Discussion}

Complete excision of the lymph node or obtaining sufficient tissue sample from the lymphoma mass lesion is the most accurate method for diagnosis of lymphoma. If sufficient tissue sample can not be obtained the subtype of the lymphoma cannot be determined accurately resulting in the patient to receive insufficient treatment or over treatment. Besides, sufficient biopsy material may not be obtained with minimally invasive methods in gastro-intestinal lymphomas. In this case, surgery may treat the complications such as obstruction, hemorrhage or perforation besides enabling the diagnosis. ${ }^{3}$ Tumor-related partial obstruction and chronic blood loss were also treated through surgery in our case.

Although the etiology of primary gastrointestinal system lymphomas has not been clearly understood, related factors include helicobacter pylori infection, rheumatic fever, Sjogren's syndrome, systemic lupus erythematosus, granulomatosus with polyangiitis, Celiac disease, inflammatory bowel diseases, and immune suppression (following organ transplantation or Hypersensitivity vasculitis infection). ${ }^{4} \mathrm{H}$. pylori infection was positive in gastric biopsy in our patient which needs to addressed later. The other factors were not present.

The initial examination of the patient diagnosed with lymphoma should include a comprehensive physical examination including performance status and all lymph nodes followed by laboratory tests (complete blood count, lactate dehydrogenase, uric acid, beta 2 microglobulin and hepatitis markers HBsAg, anti-Hbs, anti-HbclgG, immunoglobulin M- and human immundeficiency virus (HIV) markers. ${ }^{5}$ Calcium, potassium, phosphorous, uric acid and renal functions should also be analyzed in patients who have high tumor load and elevated lactate dehydrogenase. ${ }^{6}$
Our patient had negative serology for hepatitis and HIV. Postoperative lactate dehydrogenase, beta 2 microglobulin and also tumor lysis syndrome markers calcium, potassium, phosphorous, uric acid, blood urea nitrogen, and creatinine were within the normal ranges.

Early stage (1-2) bulky group $(>7.5 \mathrm{~cm})$ has a poorer prognosis than non-bulky group and the clinical course is similar with stage 3-4 disease. Therefore, this group of patients should undergo a more aggressive therapy such as 6 cycles of R-CHOP + RT. Although adding RT is not undisputable, applying RT to $>7.5 \mathrm{~cm}$ bulky node has provided a statistically significant benefit according to the RICOVER-noRTH study. ${ }^{7}$ Our patient is being treated in accordance with 6 cycles of R-CHOP + RT plan.

In conclusion, colonic lymphomas are usually diagnosed after surgical resection performed due to complications. Although surgery treats the complications of the bulky or obstructing tumor, it cannot be regarded as the primary treatment modality for lymphoma. Non-surgical therapies (chemotherapy and RT) are the cornerstone of lymphoma treatment.

\section{Ethics}

Informed Consent: Informed consent has gathered from the patient during her outpatient control.

Peer-review: Externally peer-reviewed.

\section{Authorship Contributions}

Surgical and Medical Practices: N.İ., A.D., E.Ç., C.K.P., Concept: N.İ., C.M., B.K., K.E.E., A.A., F.D., Design: N.İ., E.C.., A.D., C.K.P., B.K., C.M., Data Collection or Processing: N.İ., A.A., F.D., K.E.E., C.M., B.K., Analysis or Interpretation: N.İ., E.C., A.D., C.K.P., Literature Search: N.İ., C.K.P., F.D., A.A., Writing: N.İ., B.K., K.E.E., C.M.

Conflict of Interest: No conflict of interest was declared by the authors.

Financial Disclosure: The authors declared that this study received no financial support.

\section{References}

1. 1. Fan CW, Changchien CR, Wang JY, Chen JS, Hsu KC, Tang R, Chiang JM. Primary colorectal lymphoma. Dis Colon Rectum 2000;43:1277-1282.

2. Prochazka KT, Melchardt T, Posch F, Schlick K, Deutsch A, BehamSchmid C, Weiss L, Gary T, Neureiter D, Klieser E, Greil R, Neumeister P, Egle A, Pichler M. NCCN-IPI score-independent prognostic potential of pretreatment uric acid levels for clinical outcome of diffuse large B-cell lymphoma patients. Br J Cancer 2016;115:1264-1272.

3. Radman I, Kovacevic-Metelko J, Aurer I, Nemet D, Zupancic-Salek S, Bogdanic V, Sertic D, Mrsic M, Pulanic R, Gasparovic V, Labar B. Surgical resection in the treatment of primary gastrointestinal non-Hodgkin's lymphoma: retrospective study. Croat Med J 2002;43:555-560. 
4. Aull MJ, Buell JF, Peddi VR, Trofe J, Beebe TM, Hanaway MJ, RoyChaudhury P, Alloway RR, First MR, Woodle ES. MALToma: a Helicobacter pylori-associated malignancy in transplant patients: a report from the Israel Penn International Transplant Tumor Registry with a review of published literature. Transplantation 2003;75:225.

5. Tilly H, Gomes da Silva M, Vitolo U, Jack A, Meignan M, Lopez-Guillermo A, Walewski J, Andre M, Johnson PW, Pfreundschuh M, Ladetto M. ESMO Guidelines Committee. Diffuse large B-cell lymphoma (DLBCL): ESMO
Clinical Practice Guidelines for diagnosis, treatment and follow-up. Ann Oncol 2015;26:116-125.

6. Howard SCl, Jones DP, Pui CH. The tumor lysis syndrome. N Engl J Med 2011;364:1844-1854.

7. Held G, Murawski N, Ziepert M, Fleckenstein J, Pöschel V, Zwick C, Bittenbring J, Hänel M, Wilhelm S, Schubert J, Schmitz N, Löffler M, Rübe C, Pfreundschuh M. Role of radiotherapy to bulky disease in elderly patients with aggressive B-cell lymphoma. J Clin Oncol 2014;32:1112-1118. 